УДК 378.018.8:373.011.3-051

DOI:

Тетяна Кобилянська, здобувач

Уманського державного педагогічного університету імені Павла Тичини

\title{
ХАРАКТЕРИСТИКА ГОТОВНОСТІ ДО ПРОФЕСІЙНОЇ ДІЯЛЬНОСТІ ЯК ПЕДАГОГІЧНОЇ КАТЕГОРІї
}

У статті здійснено аналіз поняття "готовність до професійної діяльності" через різні підходи. Встановлено, що згідно функиіонального підходу вона розуміється як процес і результат формування установок особистості, особистісно-діяльнісного інтегральне психічне утворення особистості, яке формусться в діяльності, культурологічного через професійну культуру, психологічного як комплекс взаємопов'язаних та взаємозумовлених психологічних якостей, компетентнісного - передбачає те, що компетентність нормується на основі готовності, яка входить в їі структуру.

Ключові слова: функціональний підхід; психологічний підхід; компетентнісний підхід; культурологічний підхід; особистісно-діяльнісний підхід; готовність до професійної діяльності.

Jim. 15.

Tetyana Kobylyanska, Applicant

Uman Pavlo Tychyna State Pedagogical University

\section{CHARACTERISTICS OF PREPAREDNESS TO THE PROFESSIONALACTIVITY AS A PEDAGOGICALCATEGORY}

An analysis of the concept "readiness for professional activity" showed that in modern psychological and pedagogical literature, it did not receive unambiguous interpretation, which is conditioned by the specifics of the activity of a professional specialist and the peculiarities of theoretical approaches to the study of professional human activity. It is established that in spite of some differences in theoretical approaches to the interpretation of the phenomenon of "readiness for the professional activity" and its structure, it is considered in all studies as the primary and obligatory condition for successful performance of any activity.

For its characteristics, the following approaches are used: functional, psychological, competence, culturological, person-activity. It is disclosed that readiness for activity, according to a functional approach is understood as a function of the psyche, as a temporary mental state of the subject, as a process and the result of forming the settings of the individual, manifested in its activity. The essence of professional readiness through a person-activity approach, understood as the integral mental form of personality, which is formed in the activity and includes the mental states and qualities of the individual. In terms of a competent approach, readiness for the professional activity is interpreted through professional culture. The psychological approach made it possible to consider the readiness for the professional activity as a complex of interrelated and interdependent psychological qualities, the presence of which should contribute to the successful professional activity. The dialectical relationship of readiness to work and professional competence is that competence is standardized on the basis of readiness, which is part of the structure of professional competence and is regarded as its component. It is proved that readiness for professional activity is a psychic state, a complex of the personality's properties, and a level of professional culture, the integration of which is a "mental development of personality"; mental development of a person, reflecting professional readiness for activity, is the purpose and the result of its formation; multilayer education, all components of which are interconnected and interdependent, and the absence of at least one of them necessarily leads to a disproportion in the structure of the personality of a specialist.

Keywords: a functional approach; a psychological approach; a competence approach; a culturological approach; a personality-activity approach; readiness for the professional activity.

П остановка проблеми. 3 огляду на важливу роль різних показників, умов елементів, що характеризують процес підготовки фахівця до діяльності, слід в першу чергу приділити особливу увагу питанням визначення основного поняття професійної готовності як педагогічної категорії. Уточнимо, що під поняттям “готовність” розумітимемо особливий психічний стан, що виражається в наявності у суб' єкта образу структури певної дії і постійної спрямованості свідомості на їі виконання.

Очевидно, що проблема формування готовності виникає тільки в тому випадку, якщо діяльність людини в якійсь мірі нова і передбачаються певні труднощі при іïреалізації, бо, в разі звичної діяльності, проблема готовності практично вже вирішена і не усвідомлюється людиною як особливий стан. Тому, розглядаючи готовність, маємо на увазі діяльність, що вимагає змін, інновацій. 


\section{ХАРАКТЕРИСТИКАГОТОВНОСТІ ДО ПРОФЕСІЙНОӤ ДІЯЛЬНОСТІ ЯК ПЕДАГОПЧНОӤ КАТЕГОРІІ}

У цьому аспекті потребує розкриття поняття “готовність до професійної діяльності".

Аналіз основних досліджень. Готовність до професійної діяльності розглядається науковцями В. Єфименко, І. Солодиловою, Т. Галкіною, І. Яценко, Л. Лежніною, Л. Темновою як комплекс теоретичних знань, практичних умінь, особистісних властивостей і професійно значимих якостей, зумовлених вимогами до педагога і які дозволяють регулювати його діяльність; особливий особистісний стан, який передбачає наявність у суб'єкта образу структури дії і постійної спрямованості свідомості на їі виконання; психічний стан особистості, що характеризується наявністю установки на усвідомлення мети, завдань, визначенням способів діяльності.

Незважаючи на деякі розбіжності в теоретичних підходах до інтерпретації феномена

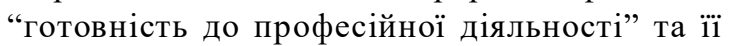
структури, вона розглядається у всіх дослідженнях як первинна і обов'язкова умова успішного виконання будь-якої діяльності.

Мета статті - розкрити поняття "готовність до професійної діяльності" через методологічні підходи (функціональний, психологічний, компетентнісний, культурологічний, особистіснодіяльнісний).

Виклад основного матеріалу. Аналіз поняття "готовність до професійної діяльності" показав, що у сучасній психолого-педагогічній літературі воно не отримало однозначного трактування, що обумовлено специфікою діяльності професіонала-фахівця і особливостями теоретичних підходів до вивчення професійної діяльності людини.

Для його розгляду у психолого-педагогічній літературі існує декілька підходів, які базуються на понятті “готовність до діяльності”, але мають і власний зміст. Умовно можна виділити такі підходи: функціональний, психологічний, компетентнісний, культурологічний, особистіснодіяльнісний.

В рамках функціонального підходу зосереджена значна кількість досліджень готовності як цілісного феномена, що вказує на налаштованість людини на діяльність, її активність і обрану поведінкову стратегію. Сучасне розуміння готовності до професійної діяльності 3 точки зору функціонального підходу Л. Лежніна характеризує як стан концентрації можливостей людини, що досягає вищого ступеня і виявляється перед, під час виконання і по завершенні певної діяльності $[7,24]$.

В рамках функціонального підходу
С. Рубінштейн вважав готовність психологічним станом активності, що характеризує схильність суб' єкта до дії певного роду та обумовлений наявністю у людини необхідних здібностей до дії [11].

Наприклад, із позицій функціонального підходу готовність до консультативної роботи розглядається Н. Байбековою як певний стан психічних функцій, який забезпечує високий рівень досягнень під час виконання консультації $[2,24]$.

Для нас представляє істотний інтерес розуміння готовності до діяльності, запропоноване Д. Узнадзе. Він трактує готовність як специфічний стан, що виникає в суб'єкті при наявності будьякої потреби і ситуації іiї задоволення. В основі цього специфічного стану лежить установка особистості до певного виду діяльності. Установки людини викликають стан готовності до діяльності і забезпечують ії цілеспрямованість. Установку як готовність до діяльності вчений розуміє як цілісне стан суб'єкта $[13,210]$.

Установка і готовність до ефективної дії достатньо близькі поняття. Установка означає відому схильність, готовність до ефективної дії, що має на увазі наявність установки на досягнення очікуваного результату. Стан готовності до ефективної діяльності виступає в якості цілісного прояву особистості. Значущою складовою готовності є здатність до ефективної діяльності. Кожна з установок повинна бути підкріплена відповідною їй здатністю до практичної реалізації $[12,24]$.

Важливо відзначити, вважає С. Комова, що установка на професійну діяльність і готовність до професійної діяльності є станами, що відрізняються один від одного. Готовність до професійної діяльності, з одного боку, не виникає окремо від установки, а, з іншого боку, являе собою більш складне змістове і структурне утворення, ніж установка $[6,47]$.

3 позиції функціонального підходу готовність до діяльності розглядається в дослідженні М. Недвецької як психічна функція, стан, наслідок сформованості особистісних установок, що реалізуються в активності суб'єкта [9, 134]

Отже, поняття готовності до професійної діяльності розглядається науковцями як категорія теорії діяльності (стан) і розуміється, з одного боку, як результат процесу підготовки, з другого установки на щось, $з$ третього розглядається як інтегративне утворення особистісних особливостей людини (переконання, погляди, риси характерутощо) іїі ситуативних психічних станів (пильність, зібраність, задоволеність тощо).

Функціональна готовність $є$ похідною від 


\section{ХАРАКТЕРИСТИКАГОТОВНОСТІ ДОПРОФЕСІЙНОӤ ДІЯЛЬНОСТІ ЯКПЕДАГОГІЧНОӤ КАТЕГОРІЇ}

особистісної. Такий комплексний аспект розгляду готовності, який акцентував єдність і взаємодію особистісних і функціональних компонентів, дозволяє вченим розглядати готовність до діяльності: як діалектичний взаємозв'язок психічного стану і якості особистості, як стійкий стан особистості, як ієрархічну систему професійно-важливих якостей і властивостей особистості, необхідних і психологічно достатніх для ефективної діяльності $[7,26]$.

В даний час професійну готовність до діяльності прийнято аналізувати як багаторівневе психічне утворення особистості. Таким чином, сутність професійної готовності вчені, які реалізують особистісно-діяльнісний підхід, розуміють як інтегральне психічне утворення особистості, яке формується в діяльності і включає психічні стани і якості особистості (О. Амосова, Н. Байбекова, М. Недвецька).

3 погляду особистісно-діяльнісного підходу готовність $є$ результатом цілеспрямованої підготовки до певної роботи. Дослідники визначають довготривалу готовність як стійкий комплекс особистісних якостей, необхідних для успішної діяльності в різних ситуаціях. Така система якостей стабільна і $є$ передумовою регуляції роботи в цілому, готовність психолога до роботи розглядається як довготривалий стан, який принципово визначає можливість успішного здійснення професійної діяльності [2, 24].

Сутність готовності до діяльності автори розуміють як інтегральну властивість особистості, яка формується в діяльності і $€$ результатом розвитку психічних процесів.

Подібне розуміння готовності ми зустрічаємо у О. Шостакович, яка вважає готовність синтезом властивостей особистості, що визначають пї здатність до діяльності. Цей синтез включає: активне позитивне ставлення до діяльності, стійкі інтелектуальні почуття, сприятливий психічний стан, певний фонд знань, умінь, навичок у відповідній галузі, здатність до конкретної діяльності.

Як бачимо, на відміну від попереднього підходу, готовність до діяльності розглядається вже не тільки як психічний стан (активність), а як синтез психічного стану (активності) і якостей особистості, як результату підготовки.

У зв'язку з цим, становить певний інтерес міркування О. Амосової, яка вивчає поняття через проблему підготовки до виховної роботи, зокрема “готовність до виховної роботи” визначає як “мету і результат підготовки; як стан індивідуальності майбутнього вчителявихователя, що полягає в певному рівні конкретних знань і умінь, що поєднуються 3 професійним інтересом до виховної роботи та грунтуються на мобільності, як інтегративній і провідній якості особистості" $[1,22]$. Ми згодні з автором у тому, що готовність це мета і результат підготовки.

Порівнюючи два підходи, можна відзначити, що на відміну від функціонального, в особистіснодіяльнісному підході не тільки як активність, як стан психіки досліджується готовність до діяльності, але і як єдність якостей особистості, сформованих в цьому процесі, і їі психічної активності $[9,135]$.

Проведений аналіз дозволяє Л. Лежніній визначити поняття готовності до професійної діяльності як сукупне психологічне новоугворення, яке полягає в спрямованості і здатності суб'єкта виконувати обрану професійну діяльність відповідно до нормативних вимог і виникає до кінця періоду професійної підготовки в результаті формування таких iĭ послідовних проявів, як готовність до вибору професії, готовність до навчальної професійної діяльності з оволодіння професією і готовність до виконання професійної діяльності $[7,44]$.

Особистісно-діяльнісний підхід до готовності виражається в розумінні її як підготовленості особистості і розглядається в зв'язку 3 формуванням, розвитком і вдосконаленням психічних процесів, станів, властивостей, необхідних для успішного виконання діяльності.

Згідно $з$ думкою більшості дослідників готовність до діяльності вивчалася науковцями двояко: з одного боку, як стан налаштованості на майбутню діяльність (ситуативна готовність), 3 іншого боку, як результат професійної підготовки (довготривала готовність).

3 позиції особистісно-діяльнісного підходу професійна готовність передбачає інтегральну характеристику особистості, що формується в діяльності і включає стан психіки і особистісні якості [9, 137].

Отже, поняття професійної готовності $є$ одночасно характеристикою особистості i характеристикою діяльності.

Культурологічний підхід в дослідженні професійної готовності формують І. Горохова, О. Шостакович, О. Шумакова. 3 позицій культурологічного підходу І. Горохова, розглядає професійну готовність як показник загальної педагогічної культури, яка полягає в загальній соціальній орієнтації людини, в значній мірі визначає іï професійне самопочуття, рівень педагогічної майстерності, ㄲï професійну компетентність і надійність $[3,30]$. Результати теоретичного аналізу категорії “професійна 


\section{ХАРАКТЕРИСТИКАГОТОВНОСТІ ДОПРОФЕСІЙНОЇ ДІЯЛЬНОСТІ ЯК ПЕДАГОГІЧНӦ̈ КАТЕГОРІЇ}

готовність” дозволили автору зробити висновок про те, що ця категорія включає в себе і психічний стан, і комплекс властивостей особистості, i рівень професійної культури.

Проведений аналіз сучасного стану проблеми привів до позначення ряду специфічних особливостей понятійного апарату щодо питань готовності до професійної діяльності, яке інтерпретується через професійну культуру.

У педагогічній психології дискусії щодо категорій культури психолога пов'язані 3 формуванням окремих іiї складових, наприклад, готовності до інноваційної діяльності. По-друге, термінологічне розмаїття в сфері професійної культури психолога обумовлене ототожненням діяльності психологів і педагогів в освіті, їх слабкою диференціацією, недостатньою концептуальною розробленістю даної проблеми, цілісних теоретичних уявлень про неї. Це пояснюється порівняльно молодою професією психолога освітнього закладу, i, як наслідок, тільки починаються активні пошуки наукових основ i практичних рекомендацій щодо вдосконалення професійної діяльності психолога освітнього закладу.

Одна з особливостей розуміння професійної культури психолога пов'язана 3 визначенням іiі змісту: суперечливість сприйняття психолога в освіті відбивається і на суперечливості змісту його професійної культури. 3 одного боку, психолог є суб' єктом освітнього процесу, що підпорядковує професійну діяльність вирішенню педагогічних завдань, що обумовлює педагогічний характер його професійної діяльності, і як наслідок, педагогічний характер його професійної культури. 3 іншого боку, професійні завдання психолога в освіті специфічні, передбачають вирішення суто психологічних завдань, що передбачає і прояв психологічного змісту його професійної культури. Розв'язання протиріччя полягає в інтеграції педагогічної та психологічної культури психолога освіти і визначенні їі сутності $[15,34]$.

Професійна готовність, як вважає О. Шостакович, це і психічний стан, і комплекс властивостей особистості, і рівень педагогічної культури. Їх інтеграція, на думку автора, і $є$ “психічне новоутворення особистості” [14, 65].

Спільними характеристиками, що зв'язують культуру психолога 3 професійною культурою фахівця освіти є сукупність професійнопедагогічних знань і досвіду їх реалізації в професійній діяльності.

Дані висновки дозволяють стверджувати, що пошук шляхів розвитку і вдосконалення професійної культури психолога необхідно вести в двох взаємопов'язаних, об'єднаних в одну систему, напрямах: перший відображає становлення інваріантних характеристик професійної культури психолога, другий розвиток i саморозвиток суб'єктних властивостей психолога освітнього закладу, що характеризують його як суб' єкта взаємодії з іншими учасниками освітнього процесу.

Психологічний пiдxiд до розкриття готовності до професійної діяльності розкривають (А. Балашова, Т. Жванія, С. Комова, Л. Лежніна, О. Райкова, А. Швалб). Науковці ії інтерпретують через психологічну готовність.

Ряд авторів розглядають поняття “професійна готовність" як похідне від психологічної готовності. Так І. Горохова аналізує професійну готовність до діяльності як багаторівневе психічне утворення особистості $[3,31]$.

Психологічна готовність відображає суб'єктний рівень готовності до діяльності, який складають соціально-психологічні та індивідуальноособистісні характеристики фахівця [7].

Психологічна готовність до професійної діяльності розглядається як комплекс взаємопов'язаних та взаємозумовлених психологічних якостей, наявність яких у майбутнього психолога має сприяти успішній професійній діяльності у галузі психології та взаємодії всіх іiї суб’єктів [4].

Грунтуючись на результатах теоретичного аналізу, під психологічною готовністю як результату психологічної підготовки І. Горохова розуміє такий вид готовності, який проявляється в сформованості певних професійно важливих якостей особистості, а також в сформованості мотивів діяльності і соціально-ціннісних орієнтацій майбутнього спеціаліста [3, 58].

Очевидно, що зміст стану психологічної готовності заснований на тих сутнісних силах людини, які найбільш актуальні для конкретного об'єкта майбутньої діяльності. Тому адекватність специфіки діяльності та забезпечення їі ефективності визначається достатнім рівнем розвитку тих складових людини, які найбільш важливі, необхідні в заданій сфері діяльності. Виходячи 3 цього, як здається С. Комовій, недоцільно протиставляти в характеристиці сугності психологічної готовності “якості” i “стан”, оскільки вони знаходяться в тісному взаємозв'язку розвиток якостей визначає рівень стану, а, визначаючи стан, ми приходимо до зміни якостей. Зміна якостей в процесі підготовки і $є$ динамікою стану психологічної готовності до діяльності $[6,55]$.

Під “психологічною готовністю студента" 


\section{ХАРАКТЕРИСТИКА ГОТОВНОСТІ ДО ПРОФЕСІЙНОӤ ДІЯЛЬНОСТІ ЯК ПЕДАГОПІЧНОӤ КАТЕГОРІЇ}

автор розуміє певний рівень професійного розвитку особистості, що передбачає сформованість системи взаємопов'язаних компонентів, що забезпечує ефективні дії в роботі з сім'єю та їі суб'єктами $[6,57]$.

Психологічна готовність до консультування, в розумінні О. Райкової, може розглядатися як складена установка в індивідуума до особистісно значущої діяльності, сполучена 3 свідомістю їі соціальною значущістю i внутрішніми механізмами виконання $[10,16]$.

Автор розглядає психологічну готовність особистості як інтегральну властивість, що включає в себе всі прояви людської природи: потреби, бажання, потяг, установки, інтереси, схильності, ідеали, переконання, цінності, світогляд, життєві цілі; формується в результаті ієрархізації мотиваційної структури особистості і обумовлює вибірковість поведінки особистості в різноманітних ситуаціях і оріснтацію діяльності на досягнення важливих цілей $[10,22]$.

Звертає на себе увагу той факт, що різні трактування феномена “психологічна готовність" і його видів обумовлені специфікою діяльності, що вивчається в кожному конкретному дослідженні і особливостями теоретичних концепцій авторів.

Таким чином, аналіз і узагальнення спеціальної літератури дозволяє нам разом із С. Комовою, зробити висновок, що під поняттям “психологічна готовність” розумітимемо результат цілеспрямованої підготовки суб'єкта до конкретної діяльності, який являє собою результативний стан людини, актуалізує найбільш важливі для заданої діяльності людські якості $[6,57]$.

Принципове значення в контексті нашого дослідження має співвіднесення понять готовності і компетентності в рамках компетентнісного підходу, оскільки остання, на наш погляд, несправедливо поглинула поняття готовності в сучасних психолого-педагогічних дослідженнях (обізнаний в будь-якій галузі та наділений певними правами і повноваженнями). Таке розуміння, що сформувалося в першу чергу в правовій сфері життєдіяльності, дозволяло довгий час розглядати компетентність як сукупність знань, умінь і навичок, що визначають здатність суб'єкта вирішувати професійні питання.

Компетентність, на думку Л. Лежніної, це виявлена в самостійній практичній діяльності готовність, тобто характеристика суб'єкта, що успішно виконує професійну діяльність, яка розвивається в самому початку професійної діяльності [7, 40].

Н. Мась визначає поняття “професійна компетентність” у майбутніх військових психологів як складне системне утворення, що дозволяе фахівцю успішно здійснювати професійну діяльність 3 навчання й виховання особового складу військового підрозділу, підтримання здорового морально-психологічного кліматув частині, інформаційно-пропагандистського забезпечення повсякденної діяльності військ $[8,4]$.

Діалектичний взаємозв'язок готовності до діяльності та професійної компетентності, на думку Л. Лежніної, полягає в тому, що компетентність нормується на основі готовності, яка входить в структуру професійної компетентності і розглядається як іiі компонент $[7,38]$.

Сутність і структура понять “готовність до професійної діяльності" і “професійна компетентність” свідчать про їх тісний взаємозв'язок. Готовність і компетентність є інтегральним багаторівневим особистісним новоутворенням, яке характеризує ступінь підготовленості до діяльності. Проте, слід зазначити, що найчастіше термін “готовність до діяльності” науковці пов'язують 3 процесом професійної підготовки, а компетентність розглядають як результат освіти $[5,39]$.

Аналіз сучасних трактувань компетентності показує, що дослідники визначають іiі не тільки як сукупність інтеграційних якостей особистості, знань, умінь, властивостей, що виражаються в здатності здійснювати діяльність, а й як урівень професійного розвитку, що виявляється в характері здійснення діяльності. Слід особливо підкреслити, що більшість авторів, що визначають компетентність акцентують увагу на наявності у суб'єкта досвіду застосування своїх знань та умінь на практиці.

На наш погляд, в психолого-педагогічних дослідженнях спостерігається протиріччя, коли професійну компетентність називають результатом професійної підготовки і одночасно розуміють іiі як досконале знання своєї справи, змісту виконуваної роботи, всіх зв'язків і відносин, як певний рівень майстерності, як індивідуальний стиль професійної діяльності, інноваційний, творчий підхід, здійснення авторських пошуків і знахідок. Такі ознаки характеризують професіонала, але не випускника закладу вищої освіти і навіть не початківця-фахівця. Іншою особливістю компетентності виступає те, що вона проявляється в діяльності, міра успішності і ефективності якої служить показником компетентності спеціаліста.

Наведених вище ознак, на наш погляд, досить для підтвердження справедливості співвідношення понять готовності до професійної діяльності і 
професійної компетентності як потенційної характеристики та їі втіленості в реальній діяльності. Вважаємо за необхідне підкреслити особливо, що пропонована диференціація понять готовності i компетентності, по-перше, спрямована на встановлення і співвіднесення як послідовність результатів суміжних етапів професіоналізації, а по-друге, не означає відходу від положень компетентнісної концепції в освіті.

Аналіз вищевикладених підходів до розкриття сутності професійної готовності дає можливість зробити такі висновки: це і психічний стан, i комплекс властивостей особистості, і рівень професійної культури, інтеграція яких і $\epsilon$ “психічним новоутворенням особистості”, тобто новим рівнем розвитку особистості, досягнутий індивідом в період навчання у закладах вищої освіти; психічне новоутворення особистості, що відображає професійну готовність до діяльності, $\epsilon$ метою і результатом іiі формування.

Таким чином, ми можемо стверджувати, що готовність до професійної діяльності це багатошарове утворення, всі компоненти якого взаємопов'язані і взаємозумовлені, і відсутність у майбутнього психолога хоча б одного 3 них обов'язково призведе до виникнення диспропорції в структурі особистості фахівця.

Висновки. Аналіз поняття "готовність до професійної діяльності” показав, що у сучасній психолого-педагогічній літературі воно не отримало однозначного трактування, що обумовлено специфікою діяльності професіоналафахівця і особливостями теоретичних підходів до вивчення професійної діяльності людини.

Для його характеристики використано такі підходи: функціональний, психологічний, компетентнісний, культурологічний, особистіснодіяльнісний. Готовність до діяльності, згідно функціонального підходу розуміється як функція психіки, як тимчасовий психічний стан суб'єкта, як процес і результат формування установок особистості, що виявляється в і1ї активності. Сутність професійної готовності через особистісно-діяльнісний підхід, розуміється як інтегральне психічне утворення особистості, яке формується в діяльності і включає психічні стани i якості особистості. 3 точки зору компетентнісного підходу готовність до професійної діяльності інтерпретується через професійну культуру. Психологічний підхід дав можливість розглядати готовність до професійної діяльності як комплекс взаємопов'язаних та взаємозумовлених психологічних якостей, наявність яких має сприяти успішній професійній діяльності. Діалектичний взаємозв'язок готовності до діяльності та професійної компетентності полягає в тому, що компетентність нормується на основі готовності, яка входить в структуру професійної компетентності і розглядається як їі компонент. Перспективу подальших досліджень вбачаємо у розкритті поняття “готовність майбутнього психолога до роботи із девіантними сім'ями" та його узгодженні 3 поняттям “готовність до професійної діяльності".

\section{ЛIТЕРАТУРА}

1. Амосова О. В. Технология подготовки студентов к воспитательной работе в современных условиях. Иркутск: Изд-во Иркутского ун-та, 2000. 220 с.

2. Байбекова Н. Формування готовності майбутніх психологів до консультативної роботи у вищих педагогічних навчальних закладах. Збірник наукових праць Уманського державного педагогічного університету. - 2013. Ч. 3. - С. 22 27.

3. Горохова И. В. Профессиональная подготовка социального педагога к работе с замещающей семьей: дис. ... канд. пед. наук. Москва, 2011. $253 \mathrm{c}$.

4. Жванія Т. В. Емоційна готовність майбутніх психологів до професійної діяльності: дис. ... канд. психол. наук. - Харків, 2012. - 190 с.

5. Затворнюк О. М. Формування у майбутніх психологів готовності до професійного самовдосконалення: дис. ... канд. пед. наук. Київ, 2016. - $310 \mathrm{c}$.

6. Комова С. Ю. Формирование психологической готовности студентов-социальных педагогов к работе с семьей: дис. ... канд. психол. наук. Воронеж, 2009. - 176 c.

7. Лежнина Л. В. Готовность психолога образования к профессиональной деятельности: этапы, механизмы, технологии формирования: дис. ... д-ра психол. наук. Москва, 2010. 489 с.

8. Мась Н. М. Психолого-педагогічні умови формування професійної компетентності у майбугніх військових психологів: автореф. дис. ... канд. психол. наук. Хмельницький, 2011. - 20 с.

9. Недвецкая М. Н. Управление качеством педагогического взаимодействия школы и семьи: дис. ... д-ра пед. наук. - Москва, 2009. - 383 с.

10. Райкова Е. Ю. Формирование психологической готовности студентов к консультированию по проблемам родительско-детских отношений: дис. ... канд. психол. наук. - Самара, 2005. - 197 с.

11. Рубинштейн С. Л. Основы общей психологии: в 2 т. Москва: Педагогика, 1989. Т. 1. - 488 с.

12. Солодилова И. В. Профессиональная 
готовность будущих социальных педагогов в вузе к работе с неполными семьями: дис. ... канд. пед. наук. - Москва, 2009. - 271 с.

13. Узнадзе Д. Н. Психологические исследования. - Москва: Наука, 1966. - 451 с.

14.ШостаковичО.А.Формированиепрофессиональной готовности студентов университета к педагогическому взаимодействию с семьей учащегося: дис. ... канд. пед. наук. - Иркутск, 2000. - 181 с.

15. Шумакова О. А. Развитие базовой культуры взаимодействия психолога образования с родителями: дис. ... д-ра психол. наук. Челябинск, 2011. - 400 с.

\section{REFERENCES}

1. Amosova, O. V. (2000). Tekhnologiya podgotovki studentov $k$ vospitatelnoy rabote $v$ sovremennykh usloviyakh [Technology of preparing students for educational work in modern conditions]. Irkutsk: House of Irkutsk University, 220 p. [in Russian].

2. Baibekova, N. (2013). Formuvannia hotovnosti maibutnikh psykholohiv do konsultatyvnoi roboty u vyshchykh pedahohichnykh navchalnykh zakladakh [Formation of readiness of future psychologists for advisory work in higher pedagogical educational institutions]. Collection of scientific works of Uman State Pedagogical University, part. 3, pp. 22-27. [in Ukrainian].

3. Horokhova, Y. V. (2011). Professionalnaya podgotovka sotsialnogo pedagoga $\mathrm{k}$ rabote $\mathrm{s}$ zameshchayushchey semey [Professional training of a social teacher to work with a foster family]. Candidate's thesis. Moscow, 253 p. [in Russian].

4. Zhvaniia, T. V. (2012). Emotsiina hotovnist maibutnikh psykholohiv do profesiinoi diialnosti [Emotional readiness of future psychologists for professional activity]. Candidate's thesis. Kharkiv, 190 p. [in Ukrainian].

5. Zatvorniuk, O. M. (2016). Formuvannia u maibutnikh psykholohiv hotovnosti do profesiinoho samovdoskonalennia [Formation of future psychologists readiness for professional selfimprovement]. Candidate's thesis. Kyiv, 310 p. [in Ukrainian].

6. Komova, S. Yu. (2009). Formirovanie psikhologicheskoy gotovnosti studentov-sotsialnykh pedagogov $\mathrm{k}$ rabote $\mathrm{s}$ semey [Formation of psychological readiness of students-social teachers to work with the family]. Candidate's thesis. Voronezh, 176 p. [in Russian].
7. Lezhnyna, L. V. (2010). Gotovnost psikhologa obrazovaniya $\mathrm{k}$ professionalnoy deyatelnosti: etapy, mekhanizmy, tekhnologii formirovaniya [Willingness of the psychologist of education for professional activities: stages, mechanisms, technologies of formation]. Doctor's thesis. Moscow, 489 p. [in Russian].

8. Mas, N. M. (2011). Psykholoho-pedahohichni umovy formuvannia profesiinoi kompetentnosti $\mathrm{u}$ maibutnikh viiskovykh psykholohiv [Psychologicalpedagogical conditions for the formation of professional competence in future military psychologists]. Extended abstract of candidate's thesis. Khmelnytskyi, 20 p. [in Ukrainian].

9. Nedvetskaia, M. N. (2009). Upravlenie kachestvom pedagogicheskogo vzaimodeystviya shkoly i semi [Managing the quality of pedagogical interaction between school and family]. Doctor's thesis. Moscow, 383 p. [in Russian].

10. Raikova, E. Yu. (2005). Formirovanie psikhologicheskoy gotovnosti studentov $\mathrm{k}$ konsultirovaniyu po problemam roditelsko-detskikh otnosheniy [Formation of psychological readiness of students for counseling on problems of parent-child relations]. Candidate's thesis. Samara, 197 p. [in Russian].

11. Rubynshtein, S. L. (1989). Osnovy obshchey psikhologii: $v 2 t$. [Basics of general psychology]. Moscov: Pedagogy, vol. 1, 488 p. [in Russian].

12. Solodylova, Y. V. (2009). Professionalnaya gotovnost budushchikh sotsialnykh pedagogov v vuze $\mathrm{k}$ rabote s nepolnymi semyami [Professional readiness of future social teachers in high school to work with single-parent families]. Candidate's thesis. Moscow, 271 p. [in Russian].

13. Uznadze, D. N. (1966). Psikhologicheskie issledovaniya [Psychological research]. Moscow: Science, 451 p. [in Russian].

14. Shostakovych, O. A. (2000). Formyrovanye professyonalnoi hotovnosty studentov unyversyteta $\mathrm{k}$ pedahohycheskomu vzaymodeistvyiu s semei uchashchehosia [Formation of professional readiness of university students for pedagogical interaction with the student's family]. Candidate's thesis. Irkutsk, 181 p. [in Russian].

15. Shumakova, O. A. (2011). Razvitie bazovoy kultury vzaimodeystviya psikhologa obrazovaniya $\mathrm{s}$ roditelyami [Development of a basic culture of interaction between an educational psychologist and parents]. Doctor's thesis. Chelyabinsk, 400 p. [in Russian].

Стаття надійшла до редакції 12.10.2018

G5808ר

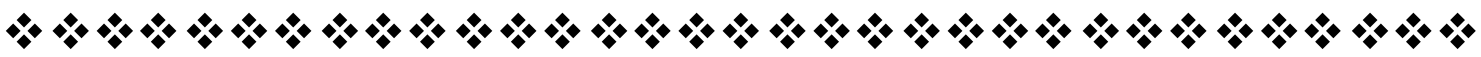

